\title{
Tema Pechman
}

\author{
Charles Pessanha
}

Depois de seis anos de enfermidade, Tema Pechman faleceu nos primeiros dias de abril. Não sem muita luta; lutou brava, corajosa, tenaz e teimosamente contra o mal que a afligiu. Sua extraordinária vitalidade permitiu que trabalhasse durante todo esse período, incluindo quase toda a edição deste número.

Graduada em ciências sociais pela Universidade Federal do Rio de Janeiro, Tema profissionalizou-se como editora científica com especialização em ciências humanas, uma área pouco afeita aos rigores e cânones do texto acadêmico. Procurou sempre dialogar com os autores e delicadamente chamar sua atenção para lacunas, sugerir uma forma mais elegante, mais precisa, menos prolixa, buscando um estilo para o texto acadêmico de ciências humanas.

Seria um exercício paciente e gratificante recolher todos os registros de agradecimentos de autores de diferentes instituições e ramos das ciências humanas em artigos, teses e livros que receberam o tratamento do seu copi, como ela costumava falar. Sua maior contribuição, entretanto, foi ao IUPERJ e, mais precisamente, a Dados - Revista de Ciências Sociais. Como secretária de redação de Dados nos últimos 15 anos, foi a principal responsável pela qualidade editorial da revista. Ainda no IUPERJ, Tema herdou o Índice de Ciências Sociais, modificou seu formato e transformou-o em uma importante base de dados on line, o DataÍndice. 
Tema deixa dois exemplos edificantes: um profundo amor à vida, demonstrado na sua coragem ao enfrentar a adversidade, o verdadeiro teste da dignidade humana, e um notável senso de profissionalismo, sempre buscando o aperfeiçoamento do seu trabalho, transmitindo seus conhecimentos para as colegas mais jovens e estagiárias que, invariavelmente, tornaram-se suas amigas e admiradoras.

O período de atuação profissional de Tema coincidiu com os anos decisivos do processo de institucionalização e profissionalização das ciências sociais em nosso País. Uma boa maneira de preservar sua memória é não perder de vista a importância e a dimensão da sua contribuição à modernização das ciências sociais na sua área de atuação. 